\title{
Jakob Leth Fink, ed.
}

Suárez on Aristotelian Causality. Investigating Medieval Philosophy 9. Brill: Leiden; Boston, 2015. Pp. 182. Hb, \$120, 93 euros.

The recent boom in publications on the philosophy of Francisco Suárez shows no sign of abating. The most recent study, Suárez on Aristotelian Causality, edited by Jakob L. Fink, aims to present Suárez's doctrine of the four Aristotelian causes, as contained in his Disputationes metaphysicae. The book consists of five chapters and an introduction. In the introductory chapter, Jacob Fink emphasizes two specific features of the book: first, Suárez's causal theory is expounded as a metaphysical problem, not as an issue of natural philosophy; second, Suárez is conceived in the book not as a transitional figure or "a missing link," connecting late medieval Scholastic philosophy with early modern rationalism and leading up to Wolff and Kant, but as a philosopher in his own right.

In Chapter One, "Suárez on Aristotelian Causality," Fink foregrounds three issues concerning general causal theory. 1) How is the definition of "cause"defined by Suárez as "a principle that per se inflows being to another thing" (Disputationes 12, 2, 3) - applicable to the four particular (i.e., material, formal, efficient, and final) causes? Is it said of them univocally, or analogically, or of some causes univocally and of others analogically? If analogically, by what kind of analogy? 2) In a link to the statement that causality is "a quasi-property of being" (Disputationes 12, Prologue) and that "being" and "cause" are thus convertible, Fink asks whether "cause," like the unity, the truth, and the good, can be regarded as a true transcendental property for Suárez. 3) Provided that metaphysics probes into the causes of its object, and considering that God is included in the object of metaphysics and does not stand outside as the mere principle (the so-called ontological conception of metaphysics), how can we speak of God having causes? In general, Fink's interpretation is none too favorable towards Suárez: Suárez fails to arrive at a unified definition of all four Aristotelian causes, and his view of the relationship between ens reale and causes remains unclear.

In Chapter Two, "Material Causality-Dissolving a Paradox: The Actuality of Prime Matter in Suárez," Erik Åkerlund considers Suárez's solution to "the central paradox of prime matter" (it is form that gives prime matter its nature and character, so that in itself prime matter must be devoid of any form; yet without any character, prime matter cannot be a real subject and cannot generate material causality). Åkerlund presents Suárez's solution based on the distinction between the metaphysical and the physical act. He stresses that this distinction is

* This review is a result of the research funded by the Czech Science Foundation as the project GA CR 14-37038G "Between Renaissance and Baroque: Philosophy and Knowledge in the Czech Lands within the Wider European Context. 
grounded in Suárez's metaphysical statement about the real identity of the essence and existence of a contingent being. While the physical act is "a sortal act" pertaining to physical form, the metaphysical act makes prime matter an incomplete substance directed toward unity with a substantial form.

Chapter Three, "Formal Causality: Giving Being by Constituting and Completing," by Kara Richardson, presents an important contribution to the contemporary debate about the role of formal causality in Suárez's metaphysics. Unlike some contemporary scholars (Robert Pasnau, Helen Hattab, Dominik Perler), Richardson comes to the conclusion that formal cause cannot be reduced to efficient cause. She convincingly shows that substantial form plays two different causal roles in Suárez's theory, the efficient and the formal, and that formal causality is fundamental. Suárez's numerous formulations indicating the efficient causality of substantial form are to be understood, above all, in the context of his reasoning against Thomist opponents, for whom substantial forms have no genuine efficient causal influence.

In Chapter Four, "Efficient Causality: The Metaphysic of Production," Stephan Schmid analyzes three issues. 1) What is the intension and extension of efficient cause? 2) What is, ontologically speaking, efficient causality or the proper way of its operation? 3) How does the efficient cause perform its causality? What are the necessary conditions of its operation? In his overall conclusion, Schmid remarks that Suárez's theory of efficient causality is substantially shaped by the assumptions of Christian theology. Consequently, the author deals above all with the issues such as divine creative efficient causality and the divine concurrence of the primary cause with secondary causes.

The last chapter, "Efficient Causality: The Metaphysics of Production," written by Sydney Penner, constitutes a "dialectical" counterpoint to the preceding chapter, whose main point of departure was the affirmation of the ontological priority of efficient causality to final causality. According to this (dominant) interpretation, Suárez, like the majority of early modern authors, started to displace final causality in favor of efficient causality. Penner argues persuasively against this interpretation and shows that it cannot be substantiated by the littera of Disputationes metaphysicae. At the same time, Penner also alerts to the fact that Suárez's verbal avowal of the authority of Aquinas - and his thesis of the priority of final cause - need not always mean full doctrinal identity with the teaching of the Angelic Doctor. The author concludes that, rather than final cause's being prior to efficient cause or efficient cause being prior to final cause, in Suárez's philosophical system the two causes are to be understood as mutual (concurrent) causes.

Generally speaking, I deem this publication to be an important and up-todate contribution to contemporary debates in the flourishing field of Suárez studies. The interpretations are conclusive and supported by a large number of 
texts taken from Disputationes metaphysicae and the recent secondary literature. The book is well-structured and clearly written. Even so, questionable or obscure formulations do appear. I will mention only one. In Chapter Two, Erik Åkerlund asserts that quantity is the only accident or the proper property that comes necessarily with matter, and that quantity and that which has quantity is co-extensive. The author goes on to infer that "Suárez comes close to the traditional position of philosophers within the nominalist school in Salamanca" (62). It has to be said that if by that claim Åkerlund means that Suárez comes close to Ockham (or Ockhamists in Salamanca) and his (their) typical claim about the real identity of quantity and material substance, i.e., to the statement of the eliminability of continuous quantity as a distinct category, this statement is simply false. As is well-known, for the sake of a metaphysical foundation for transubstantiation, Suárez in Disputationes metaphysicae 40, 2 argues for the real distinction between continuous quantity and material substance, and thus for their mutual separability.

\section{Daniel Heider}

University of South Bohemia

Daniel.Heider@seznam.cz

DOI 10.1163/22141332-00301005-02 